\title{
PERAN MUSIK DAN ASPEK KEPRIBADIAN TERHADAP KUALITAS HIDUP: STUDI KASUS TERHADAP TIGA PASIEN PASCA-STROKE DI JAKARTA
}

\author{
Irene Luvita ${ }^{l}$, \\ Lidia L. Hidajat \\ Fakultas Psikologi \\ Universitas Katolik Indonesia Atma Jaya \\ J1. Jenderal Sudirman 51, DKI Jakarta \\ Jakarta 12930, Indonesia \\ 'e-mail: irene.luvita@gmail.com
}

\begin{abstract}
Listening to music can create positive feelings such as happiness, motivation, pain reduction, increasing relaxation, and also increasing quality of life for stroke patient with depression, stress, and anxiety after stroke. The personality aspect also has a role when individuals face stroke and influences the choices of music. Materials and methods: Action research with qualitative approach. The research design used case studies and one group pre-test post test design. Participants of the present study were 3 patients (40-75 years old) and suffered from their first stroke. Data were collected by interviews, DASS questionnaire, SS-QOL, TAT personality test, and workbook as intervention activity worksheets. Results: Three of the patienst had a decline on quality of life. Two of them suffered from depression, stress, and anxiety because of stroke condition. After the intervention of listening music everyday for 2 weeks, there was an increase in quality of life across several dimensions. Music that they listened to matches the characteristics of their personality. Conclusion: The physical, psychological, and social effects of stroke can reduce the quality of life such as social roles, family roles, mood, self care, and other aspects. Listening to music everyday of their own choices can give different effects on each person and music can improve the quality of life of post-stroke patients.
\end{abstract}

Keywords: stroke; post-stroke patient; quality of life; music; personality

Abstrak - Mendengarkan musik dapat menimbulkan perasaan positif seperti perasaan bahagia, memberikan motivasi, mengurangi rasa sakit, meningkatkan relaksasi, dan meningkatkan kualitas hidup pada pasien pasca-stroke dengan depresi, stres dan kecemasan. Aspek kepribadian juga memiliki peran ketika individu menghadapi kondisi stroke dan memengaruhi pemilihan musik yang didengarkan. Metode: action research dengan pendekatan kualitatif. Desain penelitian ini menggunakan studi kasus dan one group pre-test pos-test. Partisipan penelitian terdiri dari 3 orang dengan usia 40-75 tahun dan mengalami stroke pertama. 
Pengambilan data menggunakan wawancara, kuesioner DASS, SS-QOL, alat tes kepribadian TAT, dan workbook sebagai lembar kerja aktivitas intervensi. Hasil: ditemukan bahwa ketiga Partisipan mengalami penurunan kualitas hidup. Dua di antaranya mengalami depresi, stres, dan cemas karena kondisi stroke. Setelah dilakukan intervensi berupa mendengarkan musik setiap hari selama 2 minggu, didapatkan adanya peningkatan kualitas hidup pada beberapa dimensi. Musik yang mereka dengarkan sesuai dengan karakteristik kepribadian mereka. Kesimpulan: dampak stroke baik fisik, psikologis maupun sosial dapat menurunkan kualitas hidup seperti hubungan sosial, peran keluarga, emosi, perawatan diri, dan aspek lainnya. Mendengarkan musik setiap harinya sesuai dengan pilihan sendiri memberikan efek yang berbeda-beda bagi setiap orang dan ditemukan pula bahwa musik dapat meningkatkan kualitas hidup penderita pasca-stroke.

Kata Kunci: stroke; pasien pasca-stroke; kualitas hidup; musik; kepribadian

\section{PENDAHULUAN}

Stroke merupakan penyakit kronis mematikan nomor tiga di dunia dan di Indonesia setelah penyakit jantung dan kanker. Secara global, 15 juta orang terserang stroke setiap tahunnya, sepertiga meninggal dunia dan sisanya mengalami kecacatan permanen. Pada tahun 2010, 795.000 orang mengalami stroke di Amerika (American Stroke Association, 2016). Berdasarkan data Riset Kesehatan Dasar (Riskesdas) tahun 2013 yang ditetapkan oleh Badan Penelitian dan Pengembangan Kesehatan Kementerian Kesehatan RI, terdapat 12 penderita stroke per 1000 penduduk Indonesia. Individu dengan usia 65 tahun ke atas paling berisiko terkena stroke, tetapi $25 \%$ individu yang mengalami stroke adalah orang-orang yang berusia di bawah 65 tahun.

Stroke seringkali menimbulkan perubahan kondisi fisik, psikologis, dan sosial. Studebaker (2007) menjelaskan bahwa stroke menyebabkan penurunan kemampuan fisik, antara lain hemiparesis, penurunan kontrol motorik, penurunan pada motor initiation, penurunan pada daya tahan dan kekuatan otot, gangguan menelan, gangguan kekuatan dan tonus otot, gangguan refleks, serta permasalahan pada keseimbangan. Selain perubahan kondisi fisik, individu yang mengalami stroke juga mengalami perubahan psikologis dalam hal kognitif, afektif, dan sosial.

Dalam hal kognitif, menurut Stroke Association (2012) permasalahan dalam daya ingat, kemampuan berpikir, dan memahami sesuatu pasca-stroke sering kali terjadi. Kemampuan komunikasi juga menjadi terganggu setelah serangan stroke. Permasalahan bahasa sering terjadi pada pasien yang mengalami aphasia. Selain itu dampak stroke terhadap afeksi yaitu gangguan emosi sering terjadi setelah serangan stroke dan dapat menimbulkan depresi atau kecemasan (National Heart Disease and Stroke, 2011). Prevalensi depresi paling tinggi terdapat pada 3-6 bulan pasca-stroke dan tetap tinggi sampai 1-3 tahun kemudian. D’Aniello dkk. (2014) menyatakan 
bahwa depresi, stres, dan kecemasan yang dialami individu yang mengalami stroke berkaitan juga dengan stigma atau pandangan masyarakat. Selain itu stres yang dialami individu yang mengalami stroke juga terjadi karena adanya diskrepansi antara tuntutan lingkungan dengan kemampuan yang dimiliki oleh para individu.

Terkadang ciri kepribadian yang dimiliki sebelum stroke akan berubah setelah mengalami stroke seperti orang dengan watak halus menjadi agresif, atau yang senang bersosialisasi menjadi orang yang menarik diri. Hall, Lindzey, dan Campbell (1998) menjelaskan bahwa menurut Murray, kepribadian seseorang tergantung pada fenomena-fenomena yang terjadi serta aktif tidaknya sistem saraf utama. Konsepsi Murray akan kepribadian mengasumsikan bahwa adanya proses sentral yang menyusun dan mengendalikan dalam individu. Proses-proses tersebut berfungsi menyatukan dorongan yang bertentangan dengan realita untuk memenuhi kebutuhan dan tujuan personal individu.

Stroke juga memberikan dampak terhadap kehidupan sosial penderita pasca-stroke. Stroke Recovery Association NSW (2014) menjelaskan bahwa terdapat beberapa aspek sosial yang mengalami perubahan pasca-stroke, yaitu finansial, peran sosial, seksual, dan stres keluarga. Northcott, Moss, Harrison, dan Hilari (2016) menjelaskan bahwa penderita pasca-stroke memiliki penurunan aktivitas sosial, kehidupan keluarga yang terganggu, serta hubungan dengan sosial dan pekerjaan yang berkurang. Isolasi sosial seringkali terjadi dan berhubungan dengan gangguan bahasa (aphasia). Selain itu konsekuensi sosial yang dialami individu yang mengalami stroke memiliki dampak negatif dalam hubungan dengan keluarga seperti perceraian atau perpisahan, serta tidak mampu mengatur peran sosial mereka. Perubahan perilaku dan emosi serta depresi yang dialami individu yang mengalami stroke dapat memengaruhi kualitas hidup mereka.

Kualitas hidup merupakan aspek penting dalam kehidupan seseorang. Brett dkk. (2011) mengungkapkan bahwa kualitas hidup adalah persepsi seseorang terkait posisinya di kehidupan dalam konteks sistem budaya dan nilai yang berhubungan dengan tujuan, ekspektasi, standar, dan masalahnya dalam kehidupan. Abubakar dan Isezuo (2012) mengungkapkan bahwa kualitas hidup dan kenyamanan hidup pasca-stroke menjadi isu kesehatan yang penting dan seringkali kurang diperhatikan oleh lingkungan sekitar. Stroke dapat menyebabkan menurunnya kualitas hidup meskipun mereka tidak mengalami disabilitas pasca-stroke. Penelitian yang dilakukan oleh Mierlo dkk. (2010) menjelaskan bahwa individu yang mengalami stroke harus berhadapan dengan konsekuensi seperti menurunnya kualitas hidup, reintegrasi sosial, menurunnya kenyamanan hidup, serta permasalahan fungsi emosi termasuk depresi dan kecemasan. Selain itu ditemukan pula faktor personal seperti kurangnya kemampuan dalam mengatasi permasalahan dan faktor lingkungan 
seperti dukungan sosial juga memiliki dampak yang besar terhadap kualitas hidup. Kwok, Pan, Lo, dan Song (2011) menjelaskan bahwa depresi pada pasien pasca-stroke menjadi penyebab utama buruknya kualitas hidup pasien pasca-stroke.

Sebuah penelitian yang dilakukan oleh Raglio dkk. (2015) menemukan bahwa untuk mengatasi perasaan stres, cemas, depresi, dan kurang memiliki motivasi dalam proses penyembuhan, aktivitas musik juga dapat memberikan dampak positif terhadap emosi penderita stroke yang secara tidak langsung dapat meningkatkan kualitas hidup mereka. Schellenberg (2012) menjelaskan bahwa musik memiliki pengaruh terhadap perasaan individu, dan perasaan tersebut akan memengaruhi tingkah laku mereka termasuk kemampuan kognitif (berpikir, merasakan, menyelesaikan masalah, kreativitas, dan fleksibilitas mental). Sakarmo dkk. (2008) juga menemukan bahwa mendengarkan musik pada tahap awal pasca-stroke dapat mempercepat pemulihan kognitif serta mencegah munculnya emosi negatif. Pasien yang mendengarkan musik kesukaan mereka selama 1 sampai 2 jam per hari menunjukkan peningkatakan terhadap focused attention dan memori verbal.

Hal tersebut didukung oleh Knight dan Wiese (2011) yang menemukan adanya hasil yang signifikan ketika pasien stroke mendengarkan musik sebagai pendukung terapi. Mereka menemukan adanya peningkatan dalam kecepatan, ketepatan, dan kelancaran dalam bergerak dan dapat meningkatkan kemampuan dalam melakukan aktivitas sehari-hari. Selain itu mendengarkan, menggerakkan tubuh, serta menyanyikan lagu memiliki efek positif yang mempengaruh emosi pasien stroke. Kim dkk. (2011) mengungkapkan bahwa musik dapat memengaruhi emosi pada pasien stroke seperti mengurangi kecemasan dan depresi yang dapat meningkatkan kualitas hidup mereka. Good dkk. (1999) menjelaskan bahwa musik terdiri dari nada dan ritme. Nada dan ritme tersebut tidak mengarahkan pikiran individu tetapi mengalihkannya, dan musik dapat membuat individu merasa tenang, membantu memfokuskan atensi, membantu proses pernapasan, dan menstimulasi respon relaksasi. Juslin dan Sloboda (dalam Djohan, 2010) menyatakan bahwa musik memiliki kemampuan membuat orang merasa nyaman, tetapi di kalangan para psikolog maupun medis masalah-masalah keterkaitan antara dampak musik terhadap kondisi emosional seseorang belum banyak diperhatikan, terutama pada pasien-pasien stroke.

Selain itu penelitian yang dilakukan oleh Delsing, ter Bogt, Engels, dan Meeus (2008) menemukan bahwa musik yang dipilih sendiri oleh pendengarnya menggambarkan karakteristik kepribadian mereka. Delsing dkk. juga menjelaskan bahwa menurut Eysenck dan juga Zuckerman, ketika seseorang memilih suatu musik yang ingin didengarkan, hal tersebut dilakukan untuk memenuhi kebutuhan psikologis mereka. Hal tersebut juga didukung oleh Sharma (2013) yang 
menyatakan bahwa musik favorit memiliki hubungan dengan kepribadian dan menggambarkan kebutuhan dasar psikologis mereka.

\section{METODE}

\section{Partisipan}

Penelitian ini terdiri dari 3 orang pasien pasca-stroke dengan kriteria sebagai berikut: (1) pasien yang telah didiagnosis oleh dokter mengalami stroke selama minimal 3 bulan sampai 1 tahun sejak terjadinya serangan stroke; (2) berdomisili di Jakarta; (3) tidak memiliki gangguan visual, auditori, dan verbal; berusia 40-77 tahun; dan (4) jarang mendengarkan musik setiap harinya.

\section{Desain}

Peneliti menggunakan case study sebagai desain penelitian dengan criterion sampling sebagai pengambilan sampel penelitian. Selain itu peneliti juga melakukan pengambilan data kualitas hidup sebelum dan sesudah melakukan intervensi untuk melihat efektivitas intervensi yang diberikan. Peneliti juga menggunakan penelitian eksperimen one group pre-test post-test design. Adapun desain penelitian eksperimen tersebut dapat digambarkan sebagai berikut.

Tabel 1.

\begin{tabular}{lll}
\multicolumn{3}{l}{ Skema One Group Pre-Test Post-Test Design } \\
\hline Pre-test & Perlakuan (intervensi) & Post-test \\
\hline $\mathrm{O} 1$ & $\mathrm{X} 1$ & $\mathrm{O} 2$ \\
\hline
\end{tabular}

\section{Prosedur}

Pada awal pertemuan dengan setiap Partisipan, peneliti memberikan informed consent untuk menjelaskan kesediaan Partisipan dalam melakukan program yang peneliti sediakan, kepentingan dan tujuan program, serta kerahasiaan identitas Partisipan. Kuesioner Stroke Specific Quality of Life (SS-QOL) diberikan untuk mengetahui tingkat kualitas hidup dari setiap Partisipan serta kuesioner Depression, Anxiety, Stress Scale (DASS) untuk melihat tingkat depresi, kecemasan, dan stres ketika Partisipan menghadapi kondisi pasca-stroke. Selain itu peneliti juga memberikan Thematic Apperception Test (TAT) untuk melihat kebutuhan dasar sebagai karakter kepribadian dari masingmasing Partisipan. Kebutuhan yang dimiliki oleh setiap Partisipan akan dihubungkan dengan pemilihan musik yang mereka lakukan untuk menjalani kegiatan intervensi. 
Selanjutnya Partisipan akan diminta untuk mendengarkan musik setiap harinya dan Partisipan bebas memilih sendiri musik yang ingin mereka dengarkan. Setiap kali Partisipan selesai mendengarkan musik, Partisipan akan diberikan workbook. Proses pengisian workbook dapat dilakukan oleh Partisipan maupun keluarga atau caregiver jika kondisi Partisipan tidak memungkinkan untuk melakukan pengisian. Peneliti juga melakukan in-depth interview. Pertemuan wawancara akan dilakukan sebanyak dua hingga tiga kali sesuai dengan perjanjian dengan Partisipan. Peneliti juga melakukan observasi baik ketika melakukan wawancara maupun ketika Partisipan melakukan fisioterapi di rumah sakit. Di akhir pertemuan pada minggu keempat, peneliti akan memberikan alat ukur SS-QOL untuk melihat perubahan kualitas hidup Partisipan selama mengikuti kegiatan intervensi.

SS-QOL merupakan alat ukur yang digunakan untuk mengukur kualitas hidup penderita stroke secara spesifik. Alat ukur ini dikembangkan oleh Williams, Weinberger, Harris, Clark, dan Biller (1999). Terdapat 12 dimensi yang diukur dalam alat ukur ini dengan menggunakan 5 poin skala Likert (1 adalah sangat setuju, 2 setuju, 3 netral, 4 tidak setuju, dan 5 adalah sangat tidak setuju). Koefisien alpha dari setiap domain berada antara .73 hingga .89. Sedangkan dari uji reliabilitas diperoleh hasil .94. Skor dikategorisasi menjadi lima tingkat, yaitu very poor (1.001.50); poor (1.51 - 2.50); moderate (2.51 - 3.50); good (3.51 - 4.50); excellence (4.51 - 5.00). Penilaian dilakukan dengan menjumlahkan skor-skor dari jawaban partisipan pada tiap butir. Semakin besar skor yang diperoleh makan partisipan memiliki kecenderungan mempunyai kualitas hidup yang baik.

DASS merupakan alat ukur yang digunakan untuk mengukur tingkat depresi, kecemasan serta stres seseorang. Alat ukur ini disusun oleh Lovibond dan Lovibond (1995). DASS terdiri dari 42 butir pernyataan dengan skala Likert dengan skor 0-3 (0 adalah tidak sesuai sama sekali. 1 kadang-kadang sesuai, 2 sering sesuai, sedangkan 3 adalah sangat sesuai). Skor tertinggi yang dihasilkan adalah 126 dan terendah adalah 0. Semakin tinggi skor yang didapatkan berarti semakin tinggi tingkat keparahan seseorang. DASS terdiri dari 3 bagian yaitu DASS-D (Depression), DASSA (Anxiety), dan DASS-S (Stress) dengan 14 butir pada masing-masing bagian. Skor dikategorisasi menjadi tiga tingkat untuk masing-masing bagian.

Tabel 2.

Kategorisasi DASS

\begin{tabular}{llll}
\hline & Depression & Anxiety & Stres \\
\hline Rendah & $0-7$ & $0-13$ & $0-15$ \\
Sedang & $4-15$ & $14-22$ & $16-24$ \\
Tinggi & $\geq 16$ & $\geq 23$ & $\geq 25$ \\
\hline
\end{tabular}


Sedangkan, Schultz dan Schultz (2009) menjelaskan bahwa TAT merupakan tes proyektif yang terdiri dari gambar-gambar dimana partisipan diminta untuk membuat sebuah cerita dari gambar-gambar tersebut. TAT merupakan metode untuk mengungkapkan dorongan, emosi, perasaan, kompleksitas, dan konflik dari kepribadian partisipan. TAT terdiri dari 20 kartu dengan gambar-gambar yang ambigu. Partisipan diinstruksikan untuk membuat sebuah cerita yang mengandung kejadian yang sedang terjadi, pikiran dan perasaan dari karakter pada gambar, bagaimana kejadian tersebut dapat terjadi, dan bagaimana akhir dari kejadian tersebut.

\section{Teknik Analisis}

Tahap analisis dan interpretasi data dilakukan secara kualitatif. Hasil tiap kuesioner dihitung skor total untuk mendapatkan kategori dari tiap Partisipan. Tahap analisis kualitatif didasarkan pada hasil deskriptif dan tema dari kasus yang diperoleh melalui proses wawancara. Peneliti juga menggunakan analisis tematik dimana analisis tematik adalah hasil analisis yang dilakukan pada data wawancara berdasarkan tema-tema yang sesuai dengan kerangka pemikiran sehingga membentuk sebuah pola. Pola tersebut nantinya akan menghasilkan data mengenai peran musik dan aspek kepribadian terhadap kualitas hidup pada pasien pasca-stroke.

\section{ANALISIS DAN HASIL}

\section{Kondisi Fisik Partisipan 1}

Perubahan fisik yang paling dirasakan oleh Partisipan 1 adalah pergelangan tangan hingga jarijari tangan sebelah kiri terasa kaku, bahu terasa sakit terutama ketika mengangkat tangan atau mengangkat sesuatu dengan tangan kiri, merasa keseimbangan berkurang, dan sedikit pincang ketika berjalan. Selain itu Partisipan 1 juga mengalami kesulitan untuk melakukan aktivitas seharihari tetapi ia tidak pernah meminta bantuan kepada istri atau anak-anaknya. Menurut Partisipan 1, selama hal tersebut masih dapat dilakukannya sendiri, meskipun sulit, ia akan tetap berusaha.

“...pasti menganggu kayak waktu tidur nih, saya tidak bisa lama-lama menghadap ke kiri, kelamaan sakit. Kalau nggak waktu mandi, susah buat handukan. Waktu ngambil barang juga susah. Jadi kalau ambil barang harus pakai tangan kanan, cuma kan kadang ada barang yang posisinya harus diambil pakai tangan kiri. Ya diusahakan aja pakai kiri, kalau memang nggak bisa baru pakai kanan". 


\section{Kondisi Psikologis Partisipan 1}

Partisipan 1 menyadari bahwa kondisi dirinya setelah mengalami stroke memengaruhi kehidupan sehari-hari, bahkan secara tidak langsung memengaruhi peran Partisipan 1 dalam kehidupan berumah tangga. Selain itu, kenyataan bahwa Partisipan 1 sudah tidak bekerja dan saat ini mengalami stroke membuat tekanan tersendiri meskipun stroke yang dialami Partisipan 1 tergolong ringan. Ada saat-saat di mana Partisipan 1 merasa sedih atau murung terutama mengingat kondisinya saat ini dan keuangan keluarga harus ditanggung oleh istri dan anak-anaknya.

“....ya kadang kepikiran sih, soalnya kan sekarang oom nggak kerja. Ya masih bisa sih sebenarnya kerja, kan yang kaku tangan kiri, oom masih bisa gambar pakai tangan kanan cuma ya gitu. Kayak nggak mungkin juga kerja, kondisinya gampang capek gini. Susah juga lah cari klien di usia oom sekarang. Untung NH udah kerja, terus si dedek juga kerja sambal kuliah. Tante juga kadang bantu keuangan juga. Kepikiran sih, harusnya kan oom yang kerja ya"

\section{Kondisi Sosial Partisipan 1}

Sejak terserang stroke, Partisipan 1 mengurangi aktivitas di luar rumah seperti jalan-jalan di pagi hari atau keluar dari rumah. Partisipan 1 mengaku bahwa ia belum siap untuk melakukan aktivitas di luar rumah dengan alasan bahwa kondisi tubuhnya tidak seperti dulu sebelum terserang stroke. Selain itu Partisipan 1 juga merasa mudah lelah dan menyukai keheningan atau kurang senang berada di keramaian. Jika ibu $\mathrm{N}$ atau anak-anaknya mengajak Partisipan 1 keluar rumah untuk jalan-jalan, Partisipan 1 sering menolaknya dan meminta istri dan anak-anaknya untuk pergi sendiri tanpa dirinya.

“....Sekarang oom mah jarang keluar rumah. Jalan pagi juga jarang, kalau dulu kan sering ya pagi-pagi jalan, atau sore jalan. Sekarang mah sudah nggak. Malas gitu bawaannya, kayak belum siap aja buat keluar rumah."

Tabel 3.

Hasil DASS Partisipan 1

\begin{tabular}{llll}
\hline Dimensi & Score & Rentang Score & Kategori \\
\hline Depression & 0 & $0-7$ & Rendah \\
Anxiety & 2 & $0-13$ & Rendah \\
Stres & 5 & $0-15$ & Rendah \\
\hline
\end{tabular}


Tabel 4.

Hasil SSQOL Partisipan 1

\begin{tabular}{lllll}
\hline \multirow{2}{*}{ Domain } & \multicolumn{2}{l}{ Sebelum Intervensi } & \multicolumn{2}{l}{ Sesudah Intervensi } \\
\cline { 2 - 5 } & $\begin{array}{l}\text { Skor Total / Kategori } \\
\text { jumlah item per } \\
\text { domain }\end{array}$ & $\begin{array}{l}\text { Skor Total / Kategori } \\
\text { jumlah item per } \\
\text { domain }\end{array}$ & \\
\hline Energy & $11 / 3=3.6$ & Good & $13 / 3=4.3$ & Good \\
Family Roles & $10 / 3=3.3$ & Moderate & $12 / 3=4$ & Good \\
Languange & $20 / 5=4$ & Good & $20 / 5=4$ & Good \\
Mobility & $22 / 6=3.6$ & Good & $24 / 6=4$ & Good \\
Mood & $19 / 5=3.8$ & Good & $19 / 5=3.8$ & Good \\
Personality & $9 / 3=3$ & Moderate & $11 / 3=3.6$ & Good \\
Self Care & $20 / 5=4$ & Good & $20 / 5=4$ & Good \\
Social Role & $15 / 5=3$ & Moderate & $21 / 5=4.2$ & Good \\
Thinking & $9 / 3=3$ & Moderate & $9 / 3=3$ & Moderate \\
Upper & $15 / 5=3$ & Moderate & $15 / 5=3$ & Moderate \\
function & $12 / 3=4$ & Good & $12 / 3=4$ & Good \\
Vision & $5 / 3=1.6$ & Poor & $9 / 3=3$ & Moderate \\
Productivity & & & &
\end{tabular}

\section{Kondisi Fisik Partisipan 2}

Dampak stroke terhadap fisik Partisipan 2 yang paling terlihat adalah Partisipan 2 tidak dapat berjalan dikarenakan kedua kakinya lemas, bahkan Partisipan 2 tidak dapat menggerakkan kedua kakinya. Tangan kanan pun tidak dapat digerakkan, sedangkan untuk tangan kiri Partisipan 2 masih dapat digerakkan walaupun terasa lemas. Hal ini membuat Partisipan 2 harus menghabiskan kesehariannya di ranjang. Partisipan 2 juga mengalami kesulitan bicara. Ia harus berbicara perlahan, bahkan terkadang suaranya tidak terdengar. Kalau Partisipan 2 dalam posisi duduk, ia mengaku suaranya semakin tidak keluar ketika berbicara, tetapi jika posisi tidur, ia lebih lancar dalam berbicara.

“...nggak bisa jalan, gerakin kaki juga nggak bisa. Kalau tangan kanan masih bisa digerakkin cuma lemes aja. Kalau kiri masih belum bisa. Kalau lagi tidur saya suka gerakin tangan kiri di geser-geser. Geser ke dalam bisa tapi nggak bisa keluar lagi jadi anak-anak suka bantuin."

\section{Kondisi Psikologis Partisipan 2}

Terkadang Partisipan 2 merasa sedih mengingat saat ini ia tidak dapat melakukan aktivitas apapun. Kesehariannya hanya dihabiskan di ranjang dan harus bergantung dengan orang lain untuk melakukan hal-hal rutin seperti buang air besar, mandi, makan, minum, atau bahkan hanya membalikkan tubuh ke kiri dan ke kanan. Selain itu kondisi stroke yang dialami Partisipan 2 juga membuat Partisipan 2 mengalami perubahan pola makan dan tidur. Terkadang Partisipan 2 menjadi 
kurang tertarik terhadap makanan dan porsi makan juga lebih sedikit dibandingkan sebelum stroke. Partisipan 2 juga mengalami kesulitan tidur di malam hari. Ia akan terjaga hingga pagi atau ketika sudah mulai terdengar suara orang-orang melakukan shalat subuh.

“....kadang sedih, tanya sama Tuhan kok Tuhan kasih saya sakit kayak gini. Nggak bisa ngapa-ngapain. Mau apa-apa harus minta bantuan, harus manggilmanggil dulu. Pengen cepet sembuh, supaya bisa kayak dulu lagi. ....mau balik badan waktu tidur aja harus manggil anak dulu, nggak bisa balik badan sendiri. Belum kuat."

\section{Kondisi Sosial Partisipan 2}

Partisipan 2 tidak mengalami penolakan baik dari keluarga maupun sosial. Seringkali ketika Partisipan 2 berjalan pagi menggunakan kursi roda bersama dengan anak-anaknya, banyak tetangga yang mengajak Partisipan 2 berbincang. Hanya saja Partisipan 2 merasa tidak percaya diri, terutama dengan kemampuan bicara yang terganggu. Ia merasa malu jika tetangga-tetangganya tidak mengerti apa yang ia bicarakan. Anak-anak Partisipan 2 selalu menemani Partisipan 2 setiap hari. Selain itu, adik-adik Partisipan 2 sering menghubungi Partisipan 2 melalui telepon untuk menanyakan kabar Partisipan 2. Beberapa kali sanak saudara Partisipan 2 juga berkunjung ke rumah untuk menengok Partisipan 2.

“....saya yang minder. Keluarga peduli sama saya. Tetangga juga ada yang ngajak ngobrol kalau pagi saya jalan ke depan pakai kursi roda. Tapi ya malu, biasa bisa jalan cepet. Malu kalau mereka nggak ngerti saya ngomong apa."

Tabel 5.

Hasil DASS Partisipan 2

\begin{tabular}{llll}
\hline Dimensi & Score & Rentang Score & Kategori \\
\hline Depression & 17 & $>16$ & Tinggi \\
Anxiety & 11 & $0-13$ & Rendah \\
Stres & 11 & $0-15$ & Rendah \\
\hline
\end{tabular}

Tabel 6.

Hasil SSQOL Partisipan 2

\begin{tabular}{lllll}
\hline \multirow{2}{*}{ Domain } & \multicolumn{2}{l}{ Sebelum Intervensi } & Sesudah Intervensi & \\
\cline { 2 - 5 } & $\begin{array}{l}\text { Skor Total / Kategori } \\
\text { jumlah item per } \\
\text { domain }\end{array}$ & $\begin{array}{l}\text { Skor Total / jumlah Kategori } \\
\text { item per domain }\end{array}$ & \\
\hline $\begin{array}{l}\text { Energy } \\
\text { Family Roles }\end{array}$ & $8 / 3=2.6$ & Moderate & $11 / 3=3.6$ & Good \\
Languange & $9 / 3=3$ & Moderate & $11 / 3=3.6$ & Good \\
Mobility & $6 / 5=1.6$ & Poor & $10 / 5=2$ & Poor \\
Mood & $14 / 5=2.8$ & Very poor & $6 / 6=1$ & Very poor \\
\hline
\end{tabular}




\begin{tabular}{|c|c|c|c|c|}
\hline \multirow[b]{2}{*}{ Domain } & \multicolumn{2}{|c|}{ Sebelum Intervensi } & \multicolumn{2}{|l|}{ Sesudah Intervensi } \\
\hline & $\begin{array}{l}\text { Skor Total } \\
\text { jumlah item per } \\
\text { domain }\end{array}$ & Kategori & $\begin{array}{l}\text { Skor Total / jumlah } \\
\text { item per domain }\end{array}$ & Kategori \\
\hline Personality & $9 / 3=3$ & Moderate & $11 / 3=3.6$ & Good \\
\hline Self Care & $5 / 5=1$ & Very poor & $5 / 5=1$ & Very poor \\
\hline Social Role & $13 / 5=2.6$ & Moderate & $16 / 5=3.2$ & Moderate \\
\hline Thinking & $9 / 3=3$ & Moderate & $10 / 3=3.3$ & Moderate \\
\hline $\begin{array}{l}\text { Upper extremity } \\
\text { function }\end{array}$ & $5 / 5=1$ & Very poor & $5 / 5=1$ & Very poor \\
\hline Vision & $12 / 3=4$ & Good & $12 / 3=4$ & Good \\
\hline Productivity & $6 / 3=2$ & Poor & $6 / 3=2$ & Poor \\
\hline
\end{tabular}

\section{Kondisi Fisik Partisipan 3}

Serangan stroke yang dialami Partisipan 3 menimbulkan perubahan pada fisiknya saat ini. Tangan kirinya sulit digerakkan, keseimbangan kurang baik, pincang ketika berjalan karena kaki kiri kaku, mudah lelah, bahkan sulit untuk tidur. Tiga bulan pertama setelah serangan bahkan Partisipan 3 tidak dapat berjalan dan melakukan aktivitas sehari-hari. Ia membutuhkan bantuan dari ibu L sebagai seorang istri untuk mengenakan pakaian, mandi, dan makan. Untuk buang air besar dan kecil pun Partisipan 3 mengalami kesulitan.

“....dulu saya nggak bisa jalan bu, apa-apa di kursi roda. Makan aja susah. Mandi harus dimandiin. Semua tergantung istri jadinya. Istri saya nggak bisa ninggalin saya karena setiap saat pasti saya minta bantuan. Sengsara deh 3 bulan pertama itu"

\section{Kondisi Psikologis Partisipan 3}

Kondisi stroke yang dialami oleh Partisipan 3 memengaruhi kondisi psikologis Partisipan 3. Sejak mengalami stroke, Partisipan 3 selalu merasa bahwa dirinya tidak berharga, terutama menjadi seorang suami dan ayah. Perasaan tidak berharga tersebut muncul karena Partisipan 3 tidak dapat bekerja sesering dahulu, bahkan ia berpikiran bahwa anak-anaknya mungkin merasa malu karena memiliki seorang ayah yang stroke dan cacat secara fisik. Kondisi stroke pun membuat Partisipan 3 merasa bahwa masa depannya tidak akan berjalan dengan baik. Selain itu Partisipan 3 juga mengalami kecemasan dan ketakutan bahwa kondisi fisik ini akan bertahan seumur hidupnya. Ia juga takut jika suatu saat nanti ia mengalami stroke dan tidak akan membaik atau seperti 1 tahun lalu ketika ia hanya dapat duduk di kursi roda dan bergantung pada bantuan orang lain.

“....sedih bu. Kayak saya nggak berharga lagi jadi suami dan ayah. anak-anak mungkin malu ya punya ayah pincang gini, tangganny bengkok gini. Kerja juga 
udah nggak bisa sesering dulu. ....wah masa depan saya nggak jelas deh. Pengen ini itu terhambat karena stroke. Pengen sukses mana bisa kalau fisik kayak gini (menangis ketika menceritakan apa yang dirasakan)"

\section{Kondisi Sosial Partisipan 3}

Sejak mengalami stroke, Partisipan 3 lebih menarik diri dari lingkungan sosial, terutama dari para tetangganya. Hubungan dengan teman-teman kerjanya hanya dilakukan melalui telepon karena kondisi fisik yang tidak memperbolehkan Partisipan 3 berkendara atau naik kereta dari Bogor ke Jakarta. Partisipan 3 merasa malu jika harus bertemu dengan orang lain selain keluarga. Bahkan jika terpaksa harus keluar rumah, ia memilih untuk berjalan sendiri tanpa ditemani istri atau anak. Ia merasa malu jika ia harus berjalan berdampingan dengan keluarga dan hanya dirinya yang sakit.

“....dulu sering bu ngobrol sama tetangga-tetangga. Sejak sakit jarang. Milih di rumah aja. Bahkan ke mall aja males. Malu aja kalau diliat orang ih bapak itu pincang, tangannya bengkok. Anak istrinya sehat-sehat aja padahal. Daripada kayak gitu mending saya dirumah. ....kalau terpaksa jalan sendiri aja. Malu lah anak istri pada sehat, saya aja yang cacat"

Tabel 7.

Hasil DASS Partisipan 3

\begin{tabular}{llll}
\hline Dimensi & Score & Rentang Score & Kategori \\
\hline Depression & 30 & $>16$ & tinggi \\
Anxiety & 17 & $14-22$ & sedang \\
Stres & 16 & $16-24$ & sedang \\
\hline
\end{tabular}

Tabel 8.

Hasil SSQOL Partisipan 3

\begin{tabular}{lllll}
\hline \multirow{2}{*}{ Domain } & \multicolumn{2}{l}{ Sebelum Intervensi } & \multicolumn{2}{l}{ Sesudah Intervensi } \\
\cline { 2 - 5 } & $\begin{array}{l}\text { Skor Total / Kategori } \\
\text { jumlah item } \\
\text { per domain }\end{array}$ & $\begin{array}{l}\text { Skor Total / } \\
\text { jumlah item } \\
\text { per domain }\end{array}$ & \\
\hline Energy & $5 / 3=1.6$ & Poor & $8 / 3=2.6$ & Moderate \\
\hline Family Roles & $4 / 3=1.3$ & Very poor & $11 / 3=3.6$ & Good \\
\hline Languange & $24 / 5=4.8$ & Excellence & $24 / 5=4.8$ & Excellence \\
\hline Mobility & $22 / 6=3.6$ & Good & $23 / 6=3.8$ & Good \\
\hline Mood & $9 / 5=1.8$ & Poor & $18 / 5=3.6$ & Good \\
\hline Personality & $8 / 3=2.6$ & Moderate & $11 / 3=3.6$ & Good \\
\hline Self Care & $18 / 5=3.6$ & Good & $20 / 5=4$ & Good \\
\hline Social Role & $9 / 5=1.8$ & Poor & $19 / 5=3.8$ & Good \\
\hline Thinking & $12 / 3=4$ & Good & $12 / 3=4$ & Good \\
\hline Upper extremity function & $22 / 5=4.4$ & Good & $22 / 5=4.4$ & Good \\
\hline Vision & $12 / 3=4$ & Good & $12 / 3=4$ & Good \\
\hline Productivity & $9 / 3=3$ & Moderate & $9 / 3=3$ & Moderate \\
\hline
\end{tabular}




\section{Kesimpulan Analisis}

Jika dilihat dari dampak stroke yang ditimbulkan secara fisik, Partisipan 1 dan Partisipan 3 mengalami kerusakan pada area otak kanan, hanya saja stroke yang dialami Partisipan 1 tergolong ringan sedangkan serangan stroke yang dialami Partisipan 3 lebih berat. Kedua Partisipan tersebut mengalami kaku pada bagian tubuh sebelah kiri, kesulitan berjalan, mudah lelah, keseimbangan terganggu, serta terkadang mengalami kesulitan bicara. Berbeda dengan Partisipan 2 yang mengalami kerusakan pada otak kiri yang menyebabkan kelumpuhan pada tubuh sebelah kanan, tidak dapat berjalan maupun duduk tanpa dibantu, mengalami kesulitan bicara, dan merasa mudah lelah. Jika dibandingkan dari ketiga Partisipan, Partisipan 3 mengalami kondisi pasca-stroke lebih lama yaitu sejak Januari 2016 di mana 3 bulan pertama ia mengalami kelumpuhan dan harus menghabiskan waktu di kursi roda. Partisipan 1 mengalami stroke sejak bulan September 2016, hanya saja stroke yang ia alami tergolong ringan sehingga tidak menyebabkan kelumpuhan dan masih dapat melakukan aktivitas sehari-hari. Sedangkan Partisipan 2 mengalami stroke sejak bulan November 2016 dan tergolong cukup berat yang menyebabkan kelumpuhan.

Tingkat keparahan dan lamanya para Partisipan mengalami kondisi pasca-stroke memengaruhi kondisi psikologis mereka. Jika dilihat dari tingkat keparahan dan lama sakit, kondisi stroke paling ringan dialami oleh Partisipan 1 dan kondisi stroke paling berat dan baru terjadi, yaitu sejak November 2016, dialami oleh Partisipan 2 yang menyebabkan kelumpuhan. Sedangkan untuk Partisipan 3, walaupun saat ini sudah dapat dikatakan ringan tetapi setahun sebelumnya, pada tahun 2015, Partisipan 3 juga mengalami kondisi stroke yang menyebabkan kelumpuhan.

Jika dibandingkan antara 3 Partisipan, kondisi psikologis Partisipan 3 dapat dikatakan paling buruk. Kondisi pasca-stroke menyebabkan Partisipan 3 merasa diri tidak berharga, merasa tidak memiliki masa depan, merasa bersalah kepada keluarga, muncul ketakutan mengalami kecacatan seumur hidup, dan mudah marah. Hal ini juga dipengaruhi oleh tugas perkembangan dimana usia Partisipan 3 adalah usia produktif tetapi sejak mengalami stroke produktivitas Partisipan 3 menurun. Sedangkan pada Partisipan 1 dan Partisipan 2, mereka merasa sedih karena kondisi yang mereka alami saat ini, tetapi mereka tetap bersyukur kepada Tuhan dengan kondisi yang ada. Partisipan 1 merasa bersyukur karena keluarga masih memberikan dukungan walaupun terkadang muncul perasaan menjadi beban keluarga dan Partisipan 1 terus berusaha untuk kembali produktif seperti sebelum stroke. Pada Partisipan 2, kondisi depresi yang dialami membuat Partisipan 2 mencari penguatan dari Tuhan untuk menghadapi kondisinya tersebut.

Kondisi sosial pun mengalami perubahan. Dari ketiga Partisipan, mereka menarik diri dari lingkungan dan peran dalam keluarga berubah. Pada Partisipan 2, selain karena keterbatasan 
kemampuan fisik, ia juga merasa malu jika harus keluar rumah menggunakan kursi roda. Kondisikondisi tersebut tergambar dari hasil DASS yang menyatakan bahwa Partisipan 1 tidak mengalami depresi, kecemasan, maupun stress dalam menghadapi kondisi pasca-stroke-nya. Sedangkan hasil DASS Partisipan 3 menyatakan bahwa Partisipan 3 mengalami depresi yang tinggi, kecemasan dan stress yang sedang dalam menghadapi kesehariannya. Hasil DASS milik Partisipan 2 pun menggambarkan bahwa Partisipan 2 mengalami depresi yang tinggi ketika menghadapi kondisi pasca-stroke sedangkan tingkat stres dan kecemasan masuk dalam kategori rendah.

Walaupun Partisipan 2 dan Partisipan 3 mengalami depresi, yang membedakan adalah karakter kepribadian mereka yang tergambar dalam TAT. Partisipan 3 merupakan sosok yang bergantung dengan lingkungan dan ingin dihargai oleh lingkungan. Hanya saja lingkungan tidak dapat memenuhi kebutuhan Partisipan 3 tersebut. Dalam hal ini, hubungan Partisipan 3 dengan anak pertamanya yang memburuk memberikan tekanan tersendiri bagi Partisipan 3 yang menimbulkan depresi serta rasa bersalah.

Sedangkan karakter kepribadian Partisipan 2 menunjukkan bahwa Partisipan 2 merupakan sosok yang lebih berusaha membahagiakan lingkungan sekitar dibandingkan dirinya sendiri. Selain itu ia selalu menyerahkan kondisi yang ia alami kepada Tuhan. Hal ini membantu Partisipan 2 dalam menghadapi kondisi pasca-stroke-nya. Walaupun ia merasa depresi tetapi ia masih memiliki keyakinan dan harapan di masa depan karena keingingannya untuk memenuhi kebutuhan lingkungan, terutama keluarga. Berbeda dengan Partisipan 1 yang memiliki keinginan atau usaha yang tinggi untuk mendapatkan apa yang ia inginkan. Karena Partisipan 1 tidak ingin lingkungan melihat dirinya tidak mampu, membuat Partisipan 1 berusaha sendiri membuktikan bahwa ia mampu walaupun mengalami beberapa keterbatasan fisik. Selain itu Partisipan 1 selalu berusaha untuk menyesuaikan diri dengan keadaan lingkungan saat ini.

Karakter kepribadian tersebut memengaruhi pemilihan musik yang akan didengarkan sebagai sarana intervensi. Musik yang dipilih oleh Partisipan 1 merupakan musik dengan sebagian besar bertangga nada major, tempo sedang dan cepat, pitch yang bervariasi, serta beberapa musik merupakan musik yang terkenal pada saat ini. Beberapa musik yang dipilih juga mengandung arti ungkapan rasa syukur serta pemberian motivasi. Musik yang didengarkan membuat Partisipan 1 merasa lebih bersemangat, bahagia, dan penuh rasa syukur. Berbeda dengan Partisipan 2 dimana agama menjadi sumber utama dalam hidupnya serta latar belakang budaya Jawa membuat Partisipan 2 memilih musik yang bertemakan religi. Musik yang didengarkan Partisipan 2 sebagian besar bertangga nada minor, tempo lambat sampai sedang, dan memiliki pitch yang tidak terlalu bervariasi. Musik religi sendiri memberikan kenyamanan bagi pendengarnya, ditambah dengan 
tempo lambat yang dapat membantu relaksasi. Selain itu, lirik yang terkandung dalam setiap lagu religi merupakan ungkapan rasa syukur, memohon pengampunan, serta pujian kepada Tuhan. Lagu tersebut memunculkan emosi positif seperti tenang, bahagia, semangat, bahkan membantu mengembalikan pola tidur Partisipan 2.

Berbeda dengan Partisipan 3 di mana musik yang ia pilih merupakan musik kenangan dan sebagian besar bertangga nada minor, ber-tempo lambat sampai sedang, pitch tidak beraturan, dan lirik yang terkandung menggambarkan kesedihan atau keputus-asaan. Hal ini menimbulkan emosi negatif seperti sedih, cemas, takut, karena Partisipan 3 mengingat kengangan akan hubungannya dengan anak pertamanya. Beberapa lagu yang didengarkan juga memiliki tangga nada major dengan tempo cepat yang memberikan semangat dan rasa bahagia.

Dari musik yang didengarkan, hal tersebut memengaruhi perubahan akan kualitas hidup para Partisipan. Dari ketiga Partisipan, kualitas hidup mereka mengalami peningkatan. Peningkatan paling tinggi terjadi pada Partisipan 3. Walaupun musik yang didengarkan lebih banyak menimbulkan emosi negatif, tetapi hal tersebut membuat Partisipan 3 berusaha untuk sembuh dan menunjukkan bahwa ia mampu melakukannya seorang diri. Hal tersebut dilakukan dengan harapan akan dapat mengembalikan hubungan Partisipan 3 dengan anak pertamanya. Peningkatan juga terjadi pada Partisipan 1 dan Partisipan 2. Pada Partisipan 1, ia merasa menjadi lebih bersemangat dan menjadi lebih percaya diri terutama dalam lingkungan sosial. Ia juga menjadi lebih mampu mengontrol emosi jika dihadapkan pada situasi yang tidak menyenangkan. Begitu pula dengan Partisipan 2, ia merasa lebih percaya diri dan lebih merasakan emosi positif dibandingkan sebelum melakukan aktivitas musik. Partisipan 2 juga menjadi lebih bersemangat untuk melatih otot-otot tubuh sebelah kanan agar dapat berfungsi kembali.

\section{DISKUSI}

Hasil penelitian menunjukkan bahwa intervensi berupa aktivitas mendengarkan musik berperan dalam mendukung atau menaikkan kualitas hidup pada pasien pasca-stroke. kondisi pascastroke memberikan dampak negatif bagi para penderitanya, baik secara fisik, psikologis, maupun sosial. Studebaker (2007) menyatakan bahwa para pasien pasca-stroke akan mengalami penurunan fisik seperti kelumpuhan pada bagian tubuh tertentu, penurunan kontrol motorik, penurunan daya tahan dan kekuatan otot, permasalahan pada keseimbangan, kemampuan berbahasa (kesulitan berbicara). Perubahan psikologis juga terjadi pada pasien pasca-stroke. Stroke Association (2012) 
menemukan bahwa 50\% penderita stroke menderita depresi antara 1 tahun pertama dan tergantung pada tingkat keparahan dari stroke.

Di samping itu, terdapat hal-hal yang tidak dapat dikontrol oleh peneliti yang mungkin dapat memengaruhi kualitas hidup pasien pasca-stroke seperti dukungan keluarga, dukungan sosial, dan faktor sosio-ekonomi ketika menjalani proses pengambilan data serta intervensi. Faktor usia juga memengaruhi kualitas hidup pasien pasca-stroke dimana kualitas hidup pasien pada usia produktif dengan usia dewasa akhir akan berbeda berdasarkan tugas perkembangannya.

Dari ketiga Partisipan pasca-stroke yang mengikuti program intervensi musik, melalui alat ukur DASS, 2 di antaranya mengalami depresi dan ketiganya mengalami penurunan kepercayaan diri dan pergantian peran keluarga. Gejala-gejala depresi yang dialami oleh pasien sesuai dengan pernyataan Stroke Association (2012) yaitu merasa sedih dan murung, kehilangan ketertarikan terhadap aktivitas sehari-hari, merasa tidak berguna dan kehilangan harapan, cemas, serta pola makan dan tidur berubah. Selain depresi, perubahan emosi juga terjadi pada pasien pasca-stroke. Mereka menjadi mudah marah dan tidak sabar dan hal tersebut menimbulkan stres. Mereka juga mengalami kecemasan seperti rasa kecemasan mengalami kembali serangan stroke dan merasa malu ketika berada dalam situasi sosial. Selain masalah fisik dan psikologis, kondisi pasca-stroke memberikan dampak pada kehidupan sosial. Stroke Recovery Association NSW (2014) mengungkapan bahwa beberapa aspek sosial yang mengalami perubahan antara lain kondisi finansial, peran sosial, dan stres keluarga. Hal tersebut didukung oleh Northcott dkk. (2016) yang mengungkapkan bahwa penderita pasca-stroke mengalami penurunan aktivitas sosial, bahkan seringkali terjadi isolasi sosial dan penghentian pekerjaan.

Kondisi negatif yang ditimbulkan dari stroke tersebut memengaruhi kualitas hidup mereka, di mana kualitas hidup akan menurun. Schellenberg (2012) mengungkapkan bahwa untuk mendukung peningkatan kualitas hidup pada penderita pasca-stroke, sebuah penelitian menemukan bahwa musik memiliki pengaruh terhadap emosi, kognisi, dan tingkah laku mereka. Ketiga pasien pasca-stroke yang diberikan intervensi musik menunjukkan peningkatan terhadap kualitas hidup mereka, walaupun peningkatan tersebut terjadi pada tahap yang berbeda-beda satu dengan yang lainnya.

Hasil temuan ini sesuai dengan penelitian terdahulu yang dilakukan oleh Raglio dkk. (2015) yang menunjukkan bahwa aktivitas musik dapat memengaruhi area otak seperti emosi, motivasi, kognitif, dan fungsi motorik. Selain itu musik juga dapat meningkatkan kecepatan dan pergerakan pada pasien-pasca-stroke, meningkatkan kemampuan berbahasa, membantu mempercepat 
pemulihan, dan meningkatkan hasil secara sosial dan psikologis seperti kemampuan bersosialisasi, motivasi, mood, dan mengurangi depresi.

Musik yang didengarkan oleh para pasien pasca-stroke tersebut merupakan musik yang dipilih sesuai dengan keinginan atau kesukaan mereka. Murrock dan Bekhet (2016) mengungkapkan bahwa mendengarkan musik sesuai dengan preferensi pribadi dapat meningkatkan respon psikologis, yaitu memberikan dampak pada emosional individu. Selain itu musik yang dipilih sendiri pun seringkali berhubungan dengan kehidupan atau pengalaman pribadi mereka. Hal tersebut dapat mengurangi distress serta meningkatkan relaksasi bagi pendengarnya.

Elemen-elemen yang terkandung dalam setiap musik yang dipilih oleh pasien pasca-stroke pun menimbulkan efek yang berbeda-beda. Djohan (2006) mengungkapkan bahwa musik-musik stimulatif dengan tempo yang cepat cenderung meningkatkan energi tubuh, menyebabkan tubuh bereaksi, serta meningkatkan detak jantung dan tekanan darah. Sedangkan musik sedatif atau relaksasi dengan tempo lambat dapat menurunkan detak jantung dan tekanan darah, menurunkan tingkat rangsang, dan secara umum membuat tenang. Elemen lain seperti tangga nada major atau minor, ritme, pitch, dan melodi akan memberikan efek yang berbeda-beda bagi pendengarnya.

Särkämö dkk. (2008) mengungkapkan bahwa pada pasien pasca-stroke, musik menjadi bagian dalam fisioterapi yang dapat membantu dalam proses pemulihan fungsi motorik dan bicara. Mendengarkan musik pada pasien pasca-stroke juga dapat membantu mengurangi perasaan negatif dan membantu pemulihan kognitif. Para pasien pasca-stroke melakukan intervensi dengan mendengarkan musik setiap harinya dan memberikan hasil peningkatan kualitas hidup baik dalam hal fisiologis, psikologis, maupun sosial. Hal ini sesuai dengan penelitian sebelumnya yang dilakukan oleh Antic dkk. (2012) bahwa mendengarkan musik setiap hari pada pasien pasca-stroke dapat meningkatkan kemampuan auditori, memori verbal, atensi, dan mood.

Hasil lain yang ditemukan dari penelitian ini adalah bahwa pemilihan musik dari setiap pasien pasca-stroke berkaitan dengan karakteristik kepribadian mereka, dalam hal ini adalah kebutuhan mereka. Sharma (2013) menyatakan bahwa musik favorit memiliki hubungan dengan kepribadian dan menggambarkan kebutuhan dasar psikologis mereka. Dari hasil alat ukur diagnostik TAT, ditemukan bahwa Partisipan 1 dengan needs of achievement, affiliation, autonomy, dominance, acquisition, memiliki latar belakang pendidikan terakhir Strata 2 dan status ekonomi menegah atas memilih musik atau lagu dengan tempo sedang sampai cepat, bertangga nada major, dan pitch cenderung bervariasi. Karakter elemen musik tersebut menimbulkan emosi bahagia, senang, bersemangat, dapat memberikan motivasi bagi pendengarnya, dan hal tersebut sesuai dengan teori yang diungkapkan oleh Djohan (2010). Selain itu lirik yang terkandung dari lagu yang 
dipilih merupakan ungkapan rasa syukur akan hari-hari yang dilewati. Lagu yang didengarkan pun merupakan kelompok lagu pop yang terkenal dari tahun 80an dan lagu di tahun 2016.

Pada Partisipan 2 dengan needs of nurturance, affiliation, succorance, passivity, abasement, dengan pendidikan terakhir SMP, status ekonomi menengah ke bawah, dan latar belakang budaya Jawa-Islam yang mengedepankan spiritualitas, memilih musik atau lagu dengan tempo lambat sampai sedang, bertangga nada minor, dan pitch cenderung rendah atau tinggi. Selain itu lagu yang didengarkan juga merupakan lagu religi yang mengandung ungkapan rasa syukur, permohonan ampun akan kesalahan kepada Tuhan. Elemen musik yang terkandung dalam lagu serta lirik lagu dalam musik religi tersebut menimbulkan emosi tenang, nyaman, bahkan membantu proses relaksasi. Selain itu lagu dengan tempo lambat-sedang dapat membantu memperbaiki pola tidur di malam hari. Menurut Federasi Terapi Musik Dunia (dalam Utomo \& Santoso, 2013), musik rohani atau religi dapat membuat pendengar merasakan damai yang mendalam serta kesadaran rohani yang meningkat. Menurut Skolarus dkk. (2012), spiritualitas dan optimistik secara positif memberikan efek terhadap kesehatan fisik dan mental pada pasien pasca-stroke.

Pada Partisipan 3 dengan needs of affiliation, recognition, succorance, passivity, change, dan abasement, latar pendidikan terakhir SMA, status ekonomi menengah ke atas, memilih musik atau lagu dengan tempo sedang-cepat, bertangga nada minor, dan pitch bervariasi. Selain itu lagu yang didengarkan merupakan lagu kenangan. Karakter musik tersebut memunculkan emosi sedih, tertekan, dan cemas karena lagu tersebut memunculkan kenangan masa lalu yang bahagia yang bertolak belakang dengan kondisi saat ini. Emosi-emosi tersebut menurut oleh Mierlo dkk. (2010) dapat menurunkan kualitas hidup pasien pasca-stroke.

Hasil penelitian terdahulu tersebut bertolak belakang dengan hasil yang ditemukan dalam penelitian ini. Walaupun emosi yang dimunculkan selalu negatif, tetapi terjadi peningkatan kualitas hidup pada pasien tersebut. Hal ini dikarenakan lagu yang membangkitkan kenangan masa lalu menjadikan motivasi untuk mempercepat proses pemulihan. Depresi, stres, dan kecemasan yang dialami oleh pasien pasca-stroke teratasi dengan memunculkan memori-memori masa lalu. Hallford dan Mellor (2013) mengungkapkan bahwa melakukan recall akan kenangan masa lalu merupakan bagian dari reminiscence therapy. Recall kenangan masa lalu dapat membantu meningkatkan kemampuan coping terhadap stressor untuk menyelesaikan permasalahan yang dihadapi dan meningkatkan efikasi diri. Hal ini menunjukkan bahwa pendekatan ini bekerja terhadap mekanisme spesifik untuk mengatasi depresi.

Penelitian ini memiliki beberapa keterbatasan, seperti keterbatasan jumlah pasien yang mengikuti program intervensi dan durasi intervensi yang hanya tercatat selama 2 minggu. 
Pencatatan intervensi yang hanya dilakukan selama 2 minggu dipilih oleh peneliti dengan tujuan mengurangi pengulangan dalam pengisian workbook intervensi. Selain itu salah satu pasien mengeluhkan bahwa ia harus menyediakan waktu khusus untuk mengisi evaluasi dari hasil intervensi mendengarkan musik setiap harinya. Mengacu pada keterbatasan tersebut, penelitian dan program intervensi ini dapat menjadi sebuah cara untuk mengajarkan dan memberitahukan kepada para pasien pasca-stroke serta keluarga mereka bahwa mendengarkan musik yang dilakukan setiap hari secara terus menerus dapat membantu meningkatkan atau mendukung kualitas hidup mereka. Selain itu keterbatasan penelitian ini adalah pada pasien yang tidak menjalani fisioterapi di rumah sakit. Hal ini menyebabkan peneliti belum mengetahui sejauh mana dampak aktivitas musik pada sisi fisiologis pasien pasca-stroke ketika menjani fisioterapi.

\section{SIMPULAN DAN SARAN}

Berdasarkan hasil penelitian, dapat disimpulkan bahwa kondisi stroke yang dialami para partisipan tidak selalu menimbulkan kondisi emosi depresi, kecemasan, maupun stres. Hal tersebut tergantung dari tingkat keparahan dari stroke, latar belakang kehidupan, serta kepribadian dari masing-masing individu. Selain itu mendengarkan musik setiap harinya secara rutin dapat meningkatkan kualitas hidup pasien pasca-stroke. Hanya saja aktivitas tersebut memberikan dampak yang berbeda-beda bagi setiap orang. Aktivitas mendengarkan musik dapat membantu meringankan rasa sakit ketika melakukan latihan fisik, memberikan rasa nyaman dan tenang, rasa gembira yang menimbulkan semangat dan memunculkan motivasi untuk memulihkan kondisi, membantu memperbaiki pola tidur, serta membantu proses relaksasi.

Di samping itu, aspek kepribadian, dalam hal ini berupa kebutuhan seseorang berkaitan dengan pemilihan musik yang dapat membantu atau mendukung peningkatan kualitas hidup pasien pascastroke. Selain itu dalam penelitian ini juga ditemukan bahwa status sosial-ekonomi dan pendidikan berperan terhadap cara individu menghadapi stroke. Hal terakhir adalah kondisi stroke menyebabkan penurunan kualitas hidup seseorang dalam hal energi, peran dalam keluarga, kemampuan bahasa, mobilitas, emosi, kepribadian, perawatan diri, peran sosial, proses berpikir, fungsi motorik, penglihatan, dan produktivitas. Namun, setelah diberikan intervensi berupa aktivitas mendengarkan musik, terjadi peningkatan kualitas hidup di setiap dimensinya kecuali pada Partisipan 2. Partisipan 2 tidak mengalami peningkatan kualitas hidup pada dimensi mobilitas, perawatan diri, dan fungsi motorik karena kelumpuhan yang terjadi akibat stroke. 


\section{Saran Teoretis}

Dari penelitian ini, terdapat beberapa saran teoretis yang dapat dijadikan pertimbangan untuk penelitian selanjutnya, yaitu dalam penelitian ini terfokus pada pasien pasca-stroke yang mengalami stroke pertama dengan lama sakit 3 bulan sampai 1 tahun pertama. Untuk penelitian selanjutnya, tidak hanya difokuskan pada karakteristik tersebut tapi juga dapat dibandingkan dengan pasien pasca-stroke yang mengalami sakit lebih dari 1 tahun. Hal ini bertujuan untuk melihat lebih jauh efektivitas aktivitas musik pada pasien pasca-stroke. Selanjutnya, pengambilan data dan pemberian intervensi dilakukan pada pasien-pasien yang menjalani fisioterapi di rumah sakit. Hal terakhir adalah pengambilan data dan pemberian intervensi tidak hanya dilakukan pada pasien dengan tahap perkembangan dewasa akhir dan lansia, tetapi juga pada dewasa awal yang memiliki tugas perkembangan yang berbeda.

\section{Saran Praktis}

Beberapa saran untuk pihak rumah sakait dan pasien pasca-stroke ialah sebagai berikut. Rumah sakit yang memberikan fisioterapi kepada pasien pasca-stroke dapat mengembangkan program intervensi ini, terutama kepada pasien yang sedang menjalani fisioterapi. Selanjutnya, pasien pascastroke diharapkan melakukan aktivitas musik berupa mendengarkan musik setiap harinya sesuai dengan musik yang mereka sukai. Pemilihan waktu mendengarkan musik didasarkan pada kenyamanan pasien. Akan sangat baik jika program intervensi ini juga melibatkan tenaga ahli di bidang terapi musik. Hal ini bertujuan agar mendapatkan hasil yang lebih baik dalam peningkatan kualitas hidup pasien pasca-stroke.

\section{REFERENSI}

Abubakar, S. A, \& Isezuo, S. A. (2012). Health related quality of life of stroke survivors: experience of a stroke unit. International Journal of Biomedical Science, 8(3), 183-187.

American Stroke Association. (2016). About stroke. Ditemu kembali dari http://www.strokeassociation.org

Antic, S., Morović, S., Basic Kes, V., Zavoreo, I., Jurasic, M. J., \& Demarin, V. (2012). Enhancement of stroke recovery by music. Periodicum biologorum, 114(3), 397-401

Badan Penelitian dan Pengembangan Kesehatan. (2013). Riset kesehatan dasar (Riskesdas). Jakarta: Kementerian Kesehatan RI. 
Brett, C. A., Gow, A. J., Corley, J., Pattie, A., Starr, J. M., \& Deary, I. J. (2012). Psychosocial factors and health as determinants of quality of life in community-dwelling older adults. Quality Life Research, 21, 505-516.

D’Aniello, G. E., Scarpina, F., Mauro, A., Mori, I., Castelnuovo, G., Bigoni, M., Baudo, S., \& Molinari, E. (2014). Characteristics of anxiety and psychological well-being in chronic poststroke patients. Journal of the neurological sciences, 338(1), 191-196.

Delsing M. J. M. H., ter Bogt, T. F. M., Engels, R. C. M. E., \& Meeus, W. H. J. (2008). Adolescents' music preferences and personality characteristic. European Journal of Personality, 22, 109-130

Djohan. (2006). Terapi musik, teori dan aplikasi. Yogyakarta: Galangpress.

Djohan. (2010). Respons emosi musikal. Bandung: Lubuk Agung.

Good, M., Hicks, M. S., Grass, J. A., Anderson, G. C., Choi, C., Schoolmeesters, L. J., \& Salman, A. (1999). Relief of postoperative pain with jaw relaxation, music, and their combination. Pain, 81(1), 163-172

Hall, C. S., Lindzey, G., \& Campbell, J. B. (1998). Theories of personality (4th ed). Hoboken, NJ: John Wiley \& Sons.

Hallford, D. J., \& Mellor, D. (2013). Cognitive-reminiscence therapy and usual care for depression in young adults: Study protocol for a randomized controlled trial. Trials, 14(1), 343.

Kim, D. S., Park, Y. G., Choi, J. H., Im, S. H., Jung, K. J., Cha, Y. A., Jung, C. O., \& Yoon, Y. H. (2011). Effects of music therapy on mood in stroke patients. Yonsei medical journal, 52(6), 977-981.

Knight, A. J., \& Wiese, N. (2011). Therapeutic music and nursing in poststroke rehabilitation (CE). Rehabilitation Nursing, 36(5), 204-215.

Kwok, T., Pan, J. H., Lo, R., \& Song, X. (2011). The influence of participation on health-related quality of life in stroke patients. Disability and Rehabilitation, 33(21-22), 1990-1996.

Lovibond, S. H., \& Lovibond, P. F. (1995) Manual for the depression anxiety stres scales (2nd ed.). Sydney: Psychology Foundation.

Mierlo, M. L., Heugten, C. M., Post, M. W., Lindeman, E., de Kort, P. L., \& Visser-Meily, J. (2014). A longitudinal cohort study on quality of life in stroke patients and their partners: Restore4Stroke Cohort. International journal of stroke, 9(1), 148-154.

Murrock, C. J., \& Bekhet, A. K. (2016). Concept analysis: Music therapy. Research and Theory for Nursing Practise: an International Journal, 30(1), 44-59 
National Hearth Disease and Stroke. (2011). Psychological Care After Stroke: Improving Stroke Services for People with Cognitive and Mood Disorders. Ditemu kembali dari https://www.nice.org.uk/media/default/sharedlearning/531_strokepsychologicalsupportfinal.p df

Northcott, S., Moss, B., Harrison, K., \& Hilari, K. (2015). A systematic review of the impact of stroke on social support and social networks: Associated factors and patterns of change. Clinical rehabilitation, 30(8), 811-831.

Raglio, A., Attardo, L., Gontero, G., Rollino, S., Groppo, E., \& Granieri, E. (2015). Effect of music and music therapy on mood in neurological patients. World Journal Psychiatry, 5(1), 68-78.

Särkämö, T., Tervaniemi, M., Laitinen, S., Forsblom, A., Soinila, S., Mikkonen, M., Autti, T., Silvennoinen, H. M., Erkkilä, J., Laine, M., Peretz, I., \& Hietanen, M. (2008). Music listening enhances cognitive recovery and mood after middle cerebral artery stroke. Brain, 131(3), 866876.

Schellenberg, E. G. (2012). Cognitive performance after listening to music: A review of the Mozart effect. Dalam R. A. R. McDonald, G. Kreutz, \& L. Mitchell (Eds.), Music, health, and well being (pp. 324-338). Oxford: Oxford University Press.

Schultz, D. P., \& Schultz S. E. (2009). Theories of personality (9th ed). Belmont, CA: Wadsworth.

Sharma, V. (2013). Relationship between music preference and personality type. International Journal of Science and Research.4(2), 2319-7064

Skolarus, L. E., Lisabeth, L. D., Sanchez, B. N., Smith, M. A., Garcia, N. M., Risser, J. M., \& Morgenstern, L. B. (2012). The prevalence of spirituality, optimism, depression, and fatalism in a bi-ethnic stroke population. Journal of religion and health, 51(4), 1293-1305.

Stroke Association. (2012). Memory, thinking and understanding after stroke. Ditemu kembali dari http://www.stroke.org.uk

Stroke Recovery Association NSW (2014). Social aspects. Ditemu kembali dari http://www.strokensw.org.au

Studebaker, S. E. (2007). The effect of a music therapy protocol on the attentional abilities of stroke patients (Disertasi Doktoral). Ditemu kembali dari UMI Database (UMI no. 1446276).

Utomo, A.W., \& Santoso, A. (2013). Studi pengembangan terapi musik Islami sebagai relaksasi untuk lansia. Jurnal Bimbingan dan Konseling Islam, 3(01), 62-75.

Williams, L. S., Weinberger, M., Harris, L. E., Clark, D. O., \& Biller, J. (1999). Development of a stroke-specific quality of life scale. Stroke, 30(7), 1362-1369. 